\title{
Simulations of Heterojunction and Tandem Solar Cells Based on 3C Silicon Carbide
}

\author{
Kabe Moyème ${ }^{1 *}$, Lare Yendoubé1, Ottaviani Laurent ${ }^{2}$, Pasquinelli Marcel2 ${ }^{2}$, Toure Moussa ${ }^{3}$ \\ ${ }^{1}$ Solar Energy Laboratory, University of Lome, Lome, Togo \\ ${ }^{2}$ IM2NP, Aix-Marseille University, Marseille, France \\ ${ }^{3}$ Assane Seck University of Ziguinchor, Ziguinchor, Senegal \\ Email: ${ }^{\star}$ danielkabe2@gmail.com
}

How to cite this paper: Moyème, K., Yendoubé, L., Laurent, O., Marcel, P. and Moussa, T. (2020) Simulations of Heterojunction and Tandem Solar Cells Based on 3C Silicon Carbide. Journal of Applied Mathematics and Physics, 8, 2402-2415. https://doi.org/10.4236/jamp.2020.811177

Received: September 9, 2020

Accepted: November 13, 2020

Published: November 16, 2020

Copyright (C) 2020 by author(s) and Scientific Research Publishing Inc. This work is licensed under the Creative Commons Attribution International License (CC BY 4.0)

http://creativecommons.org/licenses/by/4.0/

\begin{abstract}
In order to improve the efficiency of solar cells based on cubic silicon carbide (3C-SiC), one heterojunction solar cell and two tandem structures were simulated under AM1.5 illumination using SCAPS software. The cells' performances were studied according to the thickness of the silicon carbide layers. Simulation results allowed to achieve an efficiency of $22.03 \%$ with a tandem junction structure using an optimal thickness of 3C-SiC layer.
\end{abstract}

\section{Keywords}

Crystalline Silicon Carbide 3C-SiC, Simulation, Tandem Solar Cells

\section{Introduction}

The field of renewable energies and that of photovoltaic particularly, continue to grow today thanks to new development of techniques and especially in the improvement of photovoltaic conversion. In this area, silicon is the most used materialdespite being limited in some applications. It appeared then necessary to explore other types of materials like silicon carbide $(\mathrm{SiC})$. Silicon carbide is a large indirect band gap material which crystallizes in several forms called polytypes [1]. This material has been extensively studied due to its potential applications in variety of fields [2] such as biotechnological, harsh environment fields [3]. SiC is also known for its ability to resist to high radiation level [4], making it suitable to work in solar concentrators. Cubic silicon carbide $3 \mathrm{C}-\mathrm{SiC}$ is the polytype which offers the lower band gapvalue $2.3 \mathrm{eV}$. This material, thanks to its crystalline structure, has the possibility of being grown on silicon. So, there have been some studies on this materials for example: Shunsuke Ogawa et al. have studied a structure made of $\mathrm{TCO} / \mathrm{TiO}_{2}(40 \mathrm{~nm}) / \mathrm{n}-\mathrm{mc}-3 \mathrm{C}-\mathrm{SiC}: \mathrm{H}$ layer $(25$ 
$\mathrm{nm}) /$ intrinsic a-Si:H layer $(150 \mathrm{~nm}) / \mathrm{p}-\mathrm{mc}-\mathrm{SiCx}$ layer $(20 \mathrm{~nm}) / \mathrm{Al}$ with an efficiency of $4.6 \%$ [5], Ping-Kuan Chang et al. [6] with a structure: Glass/SnO $/$ /GZO/p-nc-SiC:H/ia-Si:H/na-Si: H/GZO/Ag whose efficiency is in the order of $8 \%$; Y. Tawada et al. [7] have developed a p-i-n cell (glass $/ \mathrm{SnO}_{2} / \mathrm{p}$ a-SiC:H/i-n a-Si:H/Al) with an efficiency of $7.55 \%$. It should also be noted that $3 \mathrm{C}-\mathrm{SiC} / \mathrm{Si}$ heterojunctions have already been studied in the domain of power diodes [8], as well as window layer or as emitter for photovoltaic cells in several configurations [9]. The opportunity to make 3C-SiC/Si tandem cells has been also studied theoretically by Heidarzadeh $\mathrm{H}$ et al. [10], and Biondo et al. [11]. This possibility of growing 3C-SiC on silicon for photovoltaic applications allowed us to initially perform work on $n-p$ cells using the SCAPS simulation software and then, elaborate and characterize the related cells [12].

In order to contribute to the improvement of the efficiency of photovoltaic cellswhile considerably reducing the number of materials to be used (case of multi-junction cells) in this better photovoltaic efficiency, the purpose of this paper is thetheoretical study, in the form of SCAPS simulation, of different structures of solar cells based on silicon carbide $3 \mathrm{C}-\mathrm{SiC}$.

\section{Material and Method}

The simulation of electrical characteristics of potential 3C-SiC based cells has been made with SCAPS 3307 software. SCAPS is a software for modeling solar cells formerly based on CdTe and CIGS [13], developed by Marc Bulgerman [14] of the Department of Electronics and Information Systems (ELIS), University of Gent, Belgium. This software can also be adapted to the simulation of other types of solar cells using other materials. The software allows to solve numerically the Poisson's equation coupled with continuity equations for both charged carrier electrons and holes under steady-state conditions.

Indeed, in semiconductor materials, exists the phenomena of transport of electric charges. So, that transport of carrier charges such as electrons and holes are described by the continuities equations of these carriers, governing the condition of dynamic equilibrium of the carriers in the semiconductor material. It is therefore a relation between the current densities, the recombination generation mechanisms and the temporal and spatial distribution of the free carrier charges. We have:

$$
\begin{aligned}
& \frac{\partial n}{\partial t}=\frac{1}{e} \operatorname{div}_{n}+G_{n}-R_{n} \\
& \frac{\partial p}{\partial t}=-\frac{1}{e} \operatorname{div}_{p}+G_{p}-R_{p}
\end{aligned}
$$

$n$ and $p$ are respectively the electron and hole densities $\left(\mathrm{cm}^{-3}\right) ; G_{n}$ and $G_{p}$ are electron and hole generation rates $\left(\mathrm{s}^{-1} \cdot \mathrm{cm}^{-3}\right), R(n, p)$, the carrier recombination rate $\left(\mathrm{s}^{-1} \cdot \mathrm{cm}^{-3}\right), J_{n}, J_{p}$, the current density of electrons and holes, and $e$, the elementary charge $(C)$.

However, the electrostatic potential being linked to the charge density of space 
$\rho$, is described by the following Poisson's equation:

$$
\Delta V=-\frac{\rho}{\varepsilon_{0} \varepsilon_{s c}} \text { with } \rho=e\left(p-n+N_{D}-N_{A}\right)
$$

where $N_{D}, N_{A}$ are the donors and acceptor concentrators; $\varepsilon_{0}$, the vacuum permittivity constant $\left(\mathrm{m}^{-3} \cdot \mathrm{kg}^{-1} \cdot \mathrm{s}^{4} \cdot \mathrm{A}^{2}\right) ; \varepsilon_{s c}$, the semiconductor permittivity constant, and $\rho$ the density of charge $\left(\mathrm{cm}^{-3}\right)$.

At one dimension, Equations (1) and (2) above can be rewritten:

$$
\begin{gathered}
\frac{\partial n}{\partial t}=\frac{1}{e} \frac{\partial J_{n}}{\partial x}+G_{n}-R_{n} \\
\frac{\partial p}{\partial t}=-\frac{1}{e} \frac{\partial J_{p}}{\partial x}+G_{p}-R_{p}
\end{gathered}
$$

The resolution of these equations requires the knowledge of the expressions of $J_{n}$ and $J_{p}$ because these current densities result from the sum of two terms, namely a concentration gradient and an electrostatic potential gradient:

$$
\begin{aligned}
& J_{n}=-e n \mu_{n} \frac{\mathrm{d} V}{\mathrm{~d} x}+e D_{n} \frac{\mathrm{d} n}{\mathrm{~d} x} \\
& J_{p}=e n \mu_{p} \frac{\mathrm{d} V}{\mathrm{~d} x}-e D_{p} \frac{\mathrm{d} p}{\mathrm{~d} x}
\end{aligned}
$$

$\mu_{n}$ and $\mu_{p}$ are electron and hole mobilities $\left(\mathrm{cm}^{2} \cdot \mathrm{V}^{-1} \cdot \mathrm{s}^{-1}\right) ; V$, the potential (V), $k_{B}$ the Boltzmann constant $\left(\mathrm{J} \cdot \mathrm{K}^{-1}\right)$, and $T$ the temperature $(\mathrm{K})$.

It follows then that the Poisson's equations and those relating to partial derivatives of one-dimensional carriers, amounts to:

$$
\begin{gathered}
\frac{\mathrm{d}^{2} V}{\mathrm{~d} x}+\frac{\rho(x)}{\varepsilon_{0} \varepsilon_{s c}}=0 \\
\frac{\partial n}{\partial t}=\frac{1}{e} \frac{\partial}{\partial x}\left(-e n \mu_{n} \frac{\mathrm{d} V}{\mathrm{~d} x}+e D_{n} \frac{\mathrm{d} n}{\mathrm{~d} x}\right)+G_{n}-R_{n} \\
\frac{\partial p}{\partial t}=-\frac{1}{e} \frac{\partial}{\partial x}\left(e n \mu_{p} \frac{\mathrm{d} V}{\mathrm{~d} x}-e D_{p} \frac{\mathrm{d} p}{\mathrm{~d} x}\right)+G_{p}-R_{p}
\end{gathered}
$$

Several parameters in the software have been taken into account such as the operating temperature, set at $300 \mathrm{~K}$ with a luminous flux of $1000 \mathrm{~W} / \mathrm{m}^{2}$, standard air mass condition under AM1.5; the thickness of the different layers, the conduction band and valence state density [15] [16], the variation of the carriers, the dielectric permittivity, the mobility of electrons and holes [17] [18] and the thermal speed of the charge carriers [15], and the band gap [19] [20]. The influence of the main parameter, namely the 3C-SiC thickness, on the photovoltaic functional characteristics such as the current density $J_{s o}$ the open circuit voltage $V_{o c}$ the fill factor FF and the efficiency $\eta$, ispresented and discussed.

\section{Results and Discussions}

The main studied parameter isthe thickness of then-type 3C-SiC layer, referring to the literatureforcarrier concentrations ranging from $10^{16}$ to $10^{19} \mathrm{~cm}^{-3}$ depending 
on the types of carrier densities, based on experimental values [21] [22]. We have also fixed the values of the carrier densities in the nSi layers to $10^{15} \mathrm{~cm}^{-3}$ [12].

A hetero-junction $\mathrm{SiC} / \mathrm{Si}$ solar cell and two different tandem solar cell structures based on 3C-SiC were considered, the simulations' results are presented in the following lines.

\subsection{Cell 1: Simple Heterojunction $n+\mathrm{SiC} / \mathrm{pSi}$}

This part shows a simple junction of the solar cell based on silicon carbide 3C which are developed in [12]. Figure 1, presents then, the stacks of the single junction cell

For this cell, we choose: $\mathrm{n}+$ SiC-3C: $\mathrm{n}+=10^{19} \mathrm{~cm}^{-3}$ with an optimal thickness of $0.2 \mathrm{um}$; $\mathrm{pSi}: \mathrm{p}=10^{15} \mathrm{~cm}^{-3}$ for a thickness of $250 \mathrm{um}$.

Figure 2 presents the I-V characteristic of the simulation of that cell and Table 1 ,

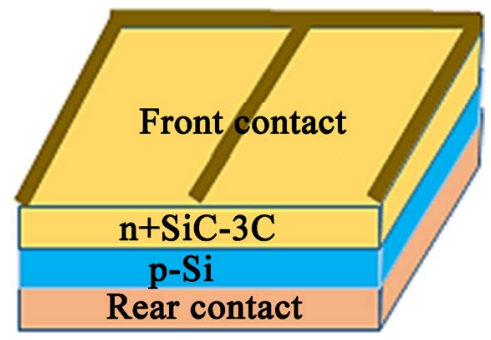

Figure 1. The simple heterojunction cell.

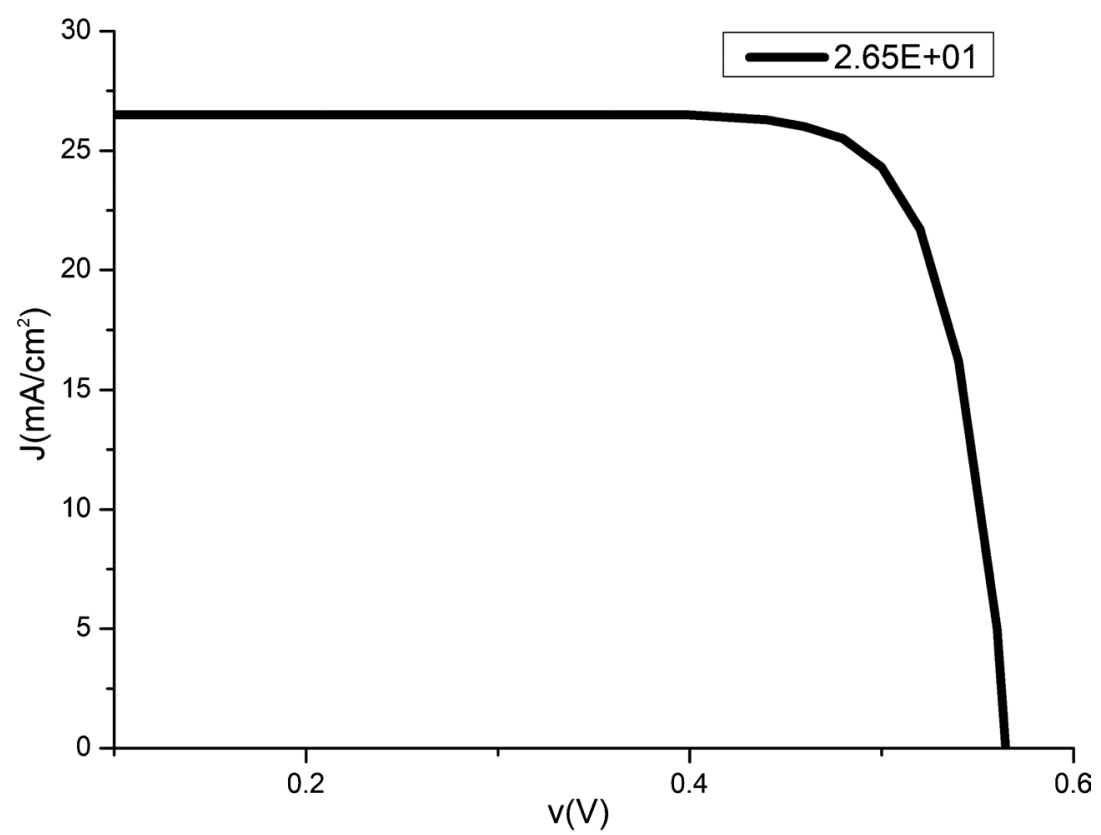

Figure 2. IV characteristic of the single junction cell 1.

Table 1. Parameters derived from the current-voltage characteristics.

\begin{tabular}{ccccc}
\hline & $J_{S C}\left(\mathrm{~mA} / \mathrm{cm}^{2}\right)$ & $V_{O C}(\mathrm{mV})$ & FF (\%) & $\eta(\%)$ \\
\hline Cell 1 & 26.5337 .81 & 565.55 & 81.58 & 17.49 \\
\hline
\end{tabular}


the parameters derived from the current-voltage characteristics.

For this cell, the efficiency is about $17.49 \%$ with an open circuit voltage of $565.55 \mathrm{mV}$. The elaboration of this cell shows that it was influenced by recombination. In order to increase the improvement of the photovoltaic conversion of this single junction cell, we defined and studied another type of the cells based on the optimal values of the thicknesses of SiC-3C. The aim of the study of this cell is to extend the space charge zone by interposing an intrinsic Si layer in order to convert more photons resulting in generation of pair electron-hole.

\subsection{Cell 2: $3 C-\operatorname{SiC}(n+) / 3 C-S i C(p) / \operatorname{Si}(i) / \operatorname{Si}(n+) / \operatorname{Si}(p+)$}

Figure 3 presents the stack of the first tandem cell investigated, cell 2: $\mathrm{n}+$ $\mathrm{SiC}-3 \mathrm{C} / \mathrm{pSiC}-3 \mathrm{C} / \mathrm{Si}(\mathrm{i}) / \mathrm{nSi} / \mathrm{p}+\mathrm{Si}$.

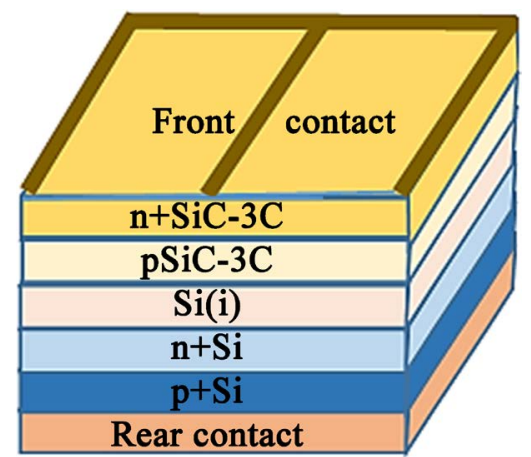

Figure 3. Stack of the solar cell $n+\mathrm{SiC}-3 \mathrm{C} / \mathrm{pSiC}-3 \mathrm{C} / \mathrm{Si}(\mathrm{i}) / \mathrm{nSi} / \mathrm{p}+\mathrm{Si}$.

This cell presents the junction of two diodes connected by an intrinsic zone. Indeed, this zone being less doped, the space charge zone will extend into this zone and consequently, the cell will be able to better absorb once illuminated, the photons of short wavelengths and those of long wavelengths. Then, in this cell, we have chosen: $\mathrm{n}+\mathrm{SiC}-3 \mathrm{C}: \mathrm{n}+=10^{19} \mathrm{~cm}^{-3}$; a p-SiC layer thickness of 0.05 um with a charge carriers density of $10^{17} \mathrm{~cm}^{-3}$; a Si(i) layer thickness of $0.01 \mathrm{um}$ and $10^{10} \mathrm{~cm}^{-3}$ of carriers' density; a $\mathrm{n}+\mathrm{Si}$ layer thickness of $0.5 \mathrm{um}$ with $10^{17}$ $\mathrm{cm}^{-3}$ carriers' density and a $\mathrm{p}+\mathrm{Si}$ layer thickness of 250 um with $10^{17} \mathrm{~cm}^{-3}$ carriers density. So, we varied the thickness of the $\mathrm{n}+\mathrm{SiC}-3 \mathrm{C}$ layer to study its influence on the performances of the cell as shown in Figure 4 and Figure 5. In the $\mathrm{pSiC}$ layer, a primary study is done and the results showed that the convergence of the parameters is obtained for $\mathrm{pSiC}$ thicknesses less than or equal to 0.1 $\mu \mathrm{m}$. The thickness of this layer was then fixed to $0.05 \mu \mathrm{m}$.

The graph presents the influence of the emitter layer on the current density Figure 4 and on the quantum efficiency Figure 5. It shows that the maximum of these parameters are obtained when the thickness of the $\mathrm{n}+\mathrm{SiC}$ is low for a value of 0.1 um (Figure 4).

As can be seen on the graphs, the thickness of the emitter layer affects the current density and therefore the efficiency of the cell. Indeed, it can be observed that the threshold thickness is about 2 um beyond which the cells' performances 


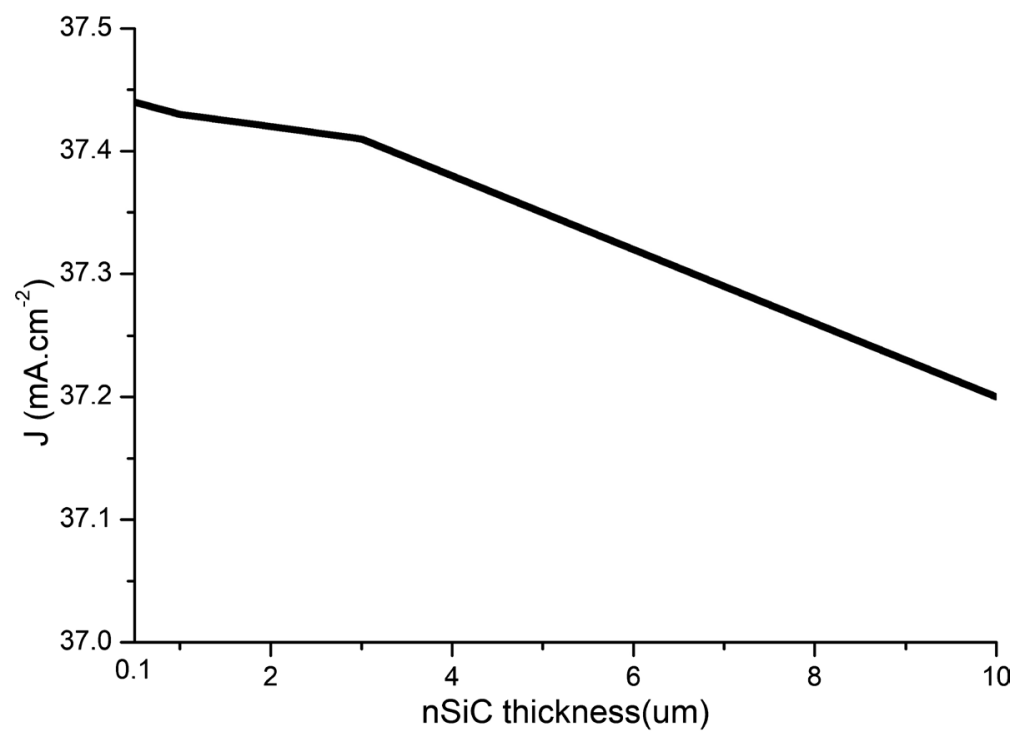

Figure 4. $J_{s c} \mathrm{vs} \mathrm{n}+\mathrm{SiC}$ thickness.

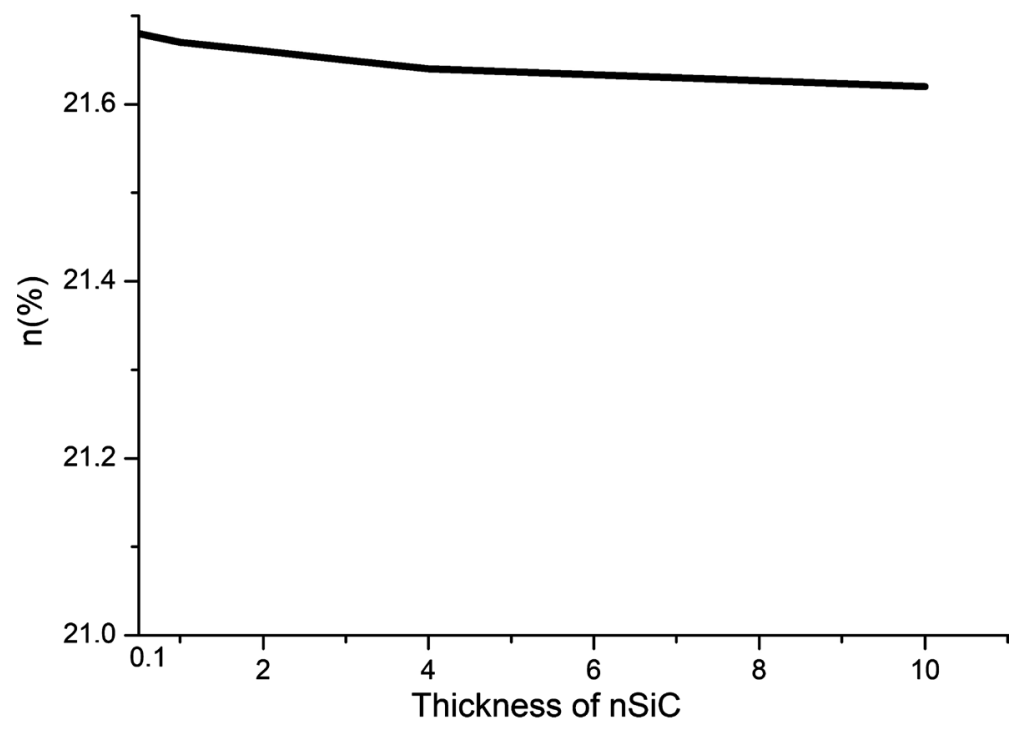

Figure 5. Quantum efficiency vs $\mathrm{n}+\mathrm{Si}$.

begin to degrade. Below the threshold thickness, the cell's efficiency is around $21.6 \%$ due to a good current density of about $37.43 \mathrm{~mA} / \mathrm{cm}^{2}$ as shown on Figure 4. The electrical behavior of that cell is presents in Figure 6, for a $\mathrm{n}+\mathrm{SiC}$ thickness of $0.1 \mathrm{um}$.

Table 2 presents the parameters of that cell.

In fact, $J_{s o}$ the current density is strongly affected by the amount of absorbed light, which correlates to the solar cell thickness and then correlates to the quantum efficiency of the solar cell, indicating how many of the generated minority charge carriers actually contribute to the power output.

Besides, the good characteristics of the cell obtained for an optimal thickness can be explained by the tunneling effect at the junction $\mathrm{pSiC}-3 \mathrm{C} / \mathrm{Si}(\mathrm{i})$ as can be observed on the cells band structure shown on Figure 7. 


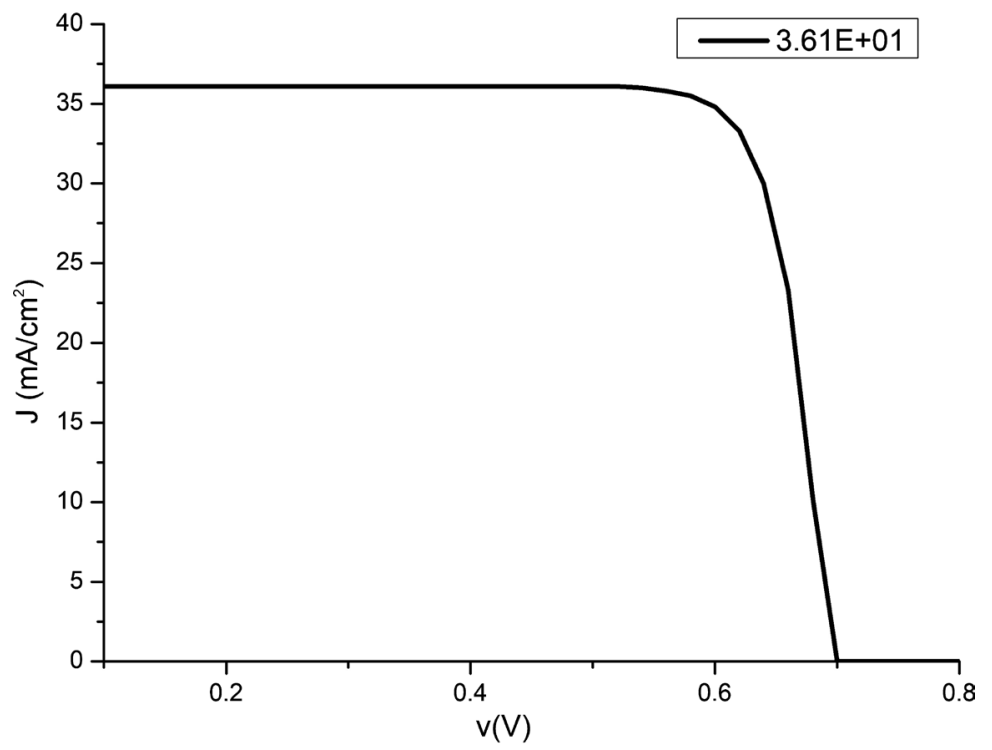

Figure 6. I-V characteristic of cell 2.

Table 2. Current-voltage characteristic parameters.

\begin{tabular}{ccccc}
\hline Thickness, $\mathrm{nSiC}-3 \mathrm{C}(\mathrm{um})$ & $J_{S C}\left(\mathrm{~mA} / \mathrm{cm}^{2}\right)$ & $V_{O C}(\mathrm{~V})$ & $\mathrm{FF}(\%)$ & $\eta(\%)$ \\
\hline 0.1 & 37.44 & 688.2 & 83.27 & 21.68 \\
3 & 37.41 & 688 & 83.27 & 21.66 \\
10 & 37.208 & 688 & 83.26 & 21.63 \\
\hline & & & \\
& &
\end{tabular}

Figure 7. Carrier transport mechanism in the cell $n+\operatorname{SiC}-3 \mathrm{C} / \mathrm{pSiC}-3 \mathrm{C} / \mathrm{Si}(\mathrm{i}) / \mathrm{n}+\mathrm{Si} / \mathrm{p}+\mathrm{Si}$.

Taking into account the electronic affinities on the first hand of the materials such as: $\mathrm{e} \chi_{\mathrm{SiC}-3 \mathrm{C}}: 4 \mathrm{eV}$ [23], e $\chi_{\mathrm{si}}: 4.01 \mathrm{eV}$ and the potential expressione $\varphi_{n, p}=k T \ln (n, p / n i)$ on the other hand using in calculations: $\mathrm{n}+\mathrm{SiC}, 1.186$ eV; pSiC: $1.067 \mathrm{eV}$; pSi: $0.299 \mathrm{eV}$, we can notice that due to the np junction between $\mathrm{n}+\mathrm{SiC}$ and $\mathrm{pSiC}$, there is a strong electrostatic field which allows the charge carriers (electrons) to easily overcome the potential barrier of $0.12 \mathrm{eV}$ and to pass from the $\mathrm{n}+\mathrm{SiC}$, rich an electron to $\mathrm{pSiC}$ poor an electron. Finally, at the junction $\mathrm{pSiC} / \mathrm{n}+\mathrm{Si}$, the charge carriers pass through by tunnel effect as shown in Figure 7. So, the potential barriers between $\mathrm{nSi}$ and $\mathrm{pSi}$ of $0.12 \mathrm{eV}$, being low, the carriers of charges are easily collected, hence the performance of the cell.

After the results obtained with cell 1 , we investigated another structure in which the potential barrier between $\mathrm{n}+\mathrm{SiC}-3 \mathrm{C}$ and $\mathrm{pSiC}-3 \mathrm{C}$ could be reduced 
by inserting a nSiC-3C layer. Moreover, a tunnel junction is created to allow a transition of carriers' charges. The results are presented in the following section.

\subsection{Cell 3: 3C-SiC(n+)/3C-SiC(n)/3C-SiC(p)/3C-SiC(p++)/ $\mathrm{Si}(\mathrm{n}++) / \operatorname{Si}(\mathrm{n}+) / \mathrm{Si}(\mathrm{p}+)$}

The stack of the tandem cell, cell 3, is presented on Figure 8.

For this cell, the junction of the two diodes is connected by a tunnel junction delimited by two regions $\mathrm{N}$ and $\mathrm{P}$, with high doping. So, the optimal parameters of $\mathrm{n}+\mathrm{SiC}-3 \mathrm{C}$ layer have been studied in cell 1 , for this cell 3 , we studied the influence of the thickness of $\mathrm{p}+\mathrm{SiC}-3 \mathrm{C}$ layer with a doping of $10^{17} \mathrm{~cm}^{-3}$, using optimized thicknesses of all other layers: $\mathrm{n}+\mathrm{SiC}-3 \mathrm{C}: 0.1 \mathrm{um}, \mathrm{n}+=10^{19} \mathrm{~cm}^{-3}$; nSiC-3C: 0.05 um, $\mathrm{n}=10^{17} \mathrm{~cm}^{-3} ; \mathrm{p}++\mathrm{SiC}-3 \mathrm{C}: 0.01 \mathrm{um}, \mathrm{p}++=10^{19} \mathrm{~cm}^{-3} ; \mathrm{n}++\mathrm{Si}:$ $0.01 \mathrm{um}, \mathrm{n}++=10^{18} \mathrm{~cm}^{-3} ; \mathrm{n}+\mathrm{Si}: 0.2 \mathrm{um}, \mathrm{n}+=10^{17} \mathrm{~cm}^{-3}$ and $\mathrm{p}+\mathrm{Si}: 250 \mathrm{um}, \mathrm{p}+$ $=10^{17} \mathrm{~cm}^{-3}$.

The results are presented in the following graphs (Figure 9).

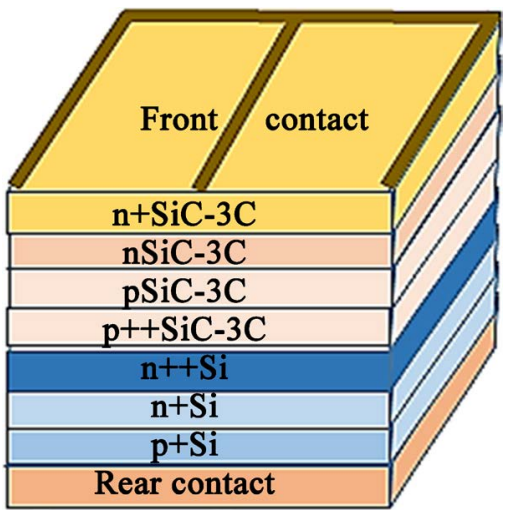

Figure 8. Stack of cell 3: $3 \mathrm{C}-\mathrm{SiC}(\mathrm{n}+) / 3 \mathrm{C}-\mathrm{SiC}(\mathrm{n}) / 3 \mathrm{C}-\mathrm{SiC}(\mathrm{p}+) / 3 \mathrm{C}-\mathrm{SiC}(\mathrm{p}++) / \mathrm{Si}(\mathrm{n}++) /$ $\operatorname{Si}(\mathrm{n}+) / \operatorname{Si}(\mathrm{p}+)$.

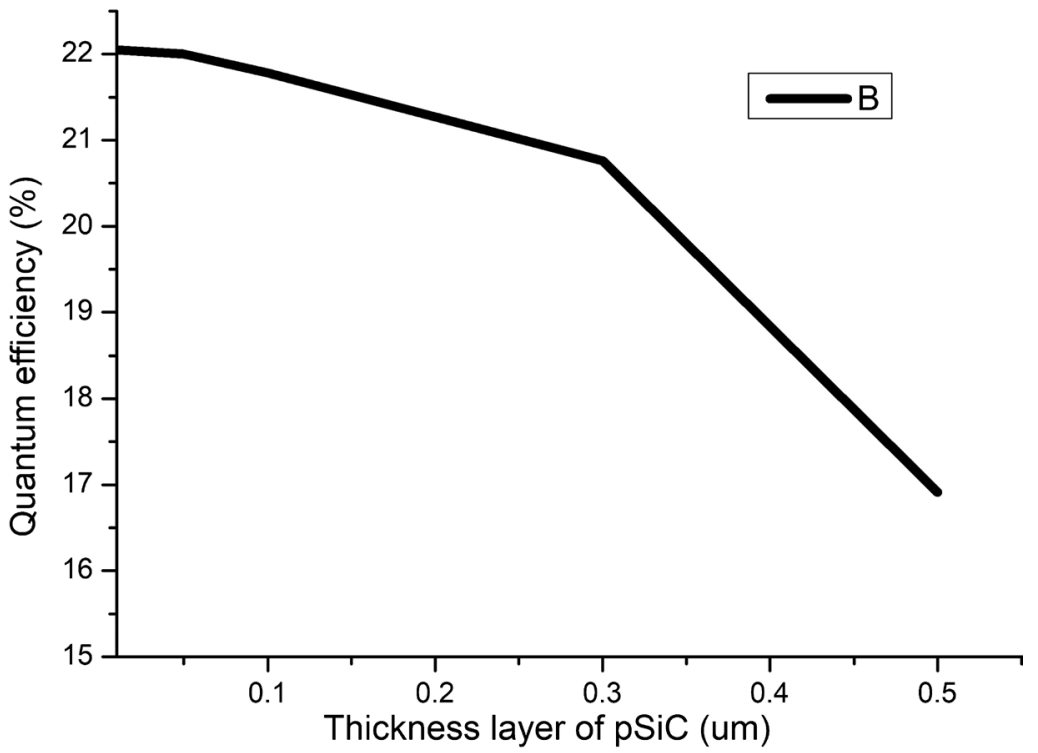

Figure 9. Quantum efficiency vs pSiC thickness. 
As can be seen on Figure 9, the quantum efficiency decreases gradually as the thickness of the pSiC layer becomes more important. From Figure 9, it can be remarked that the threshold thickness is about 0.5 um beyond which the cells' performances begin to degrade. It is then profitable for the cell to choose the smallest possible thickness. So, we fixed the pSiC layer thickness to $0.01 \mathrm{um}$.

Figure 10 and Table 3 show respectively the I-V graph and the functional characteristics of the cell obtained.

Figure 11 shows the band structure of that cell 3. It is can be seen that the potential between $\mathrm{nSiC}-3 \mathrm{C}$ and $\mathrm{pSiC}-3 \mathrm{C}$ of $0.06 \mathrm{eV}$, is effectively reduced, which influenced positively the performances of the cell.

This structure performed an efficiency of 22.03\%; an improvement of the photovoltaic conversion compared to cell 1 and the single junction cell of our

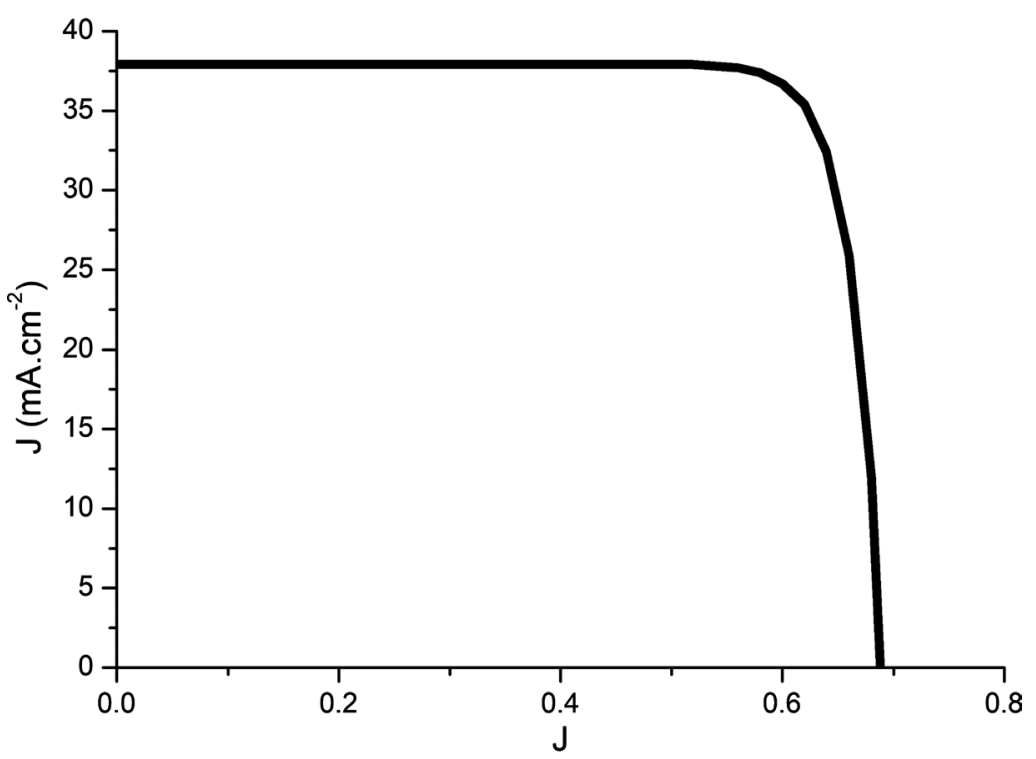

Figure 10. I-V characteristic of the cell 3.

Table 3. Parameters derived from current-voltage characteristics.

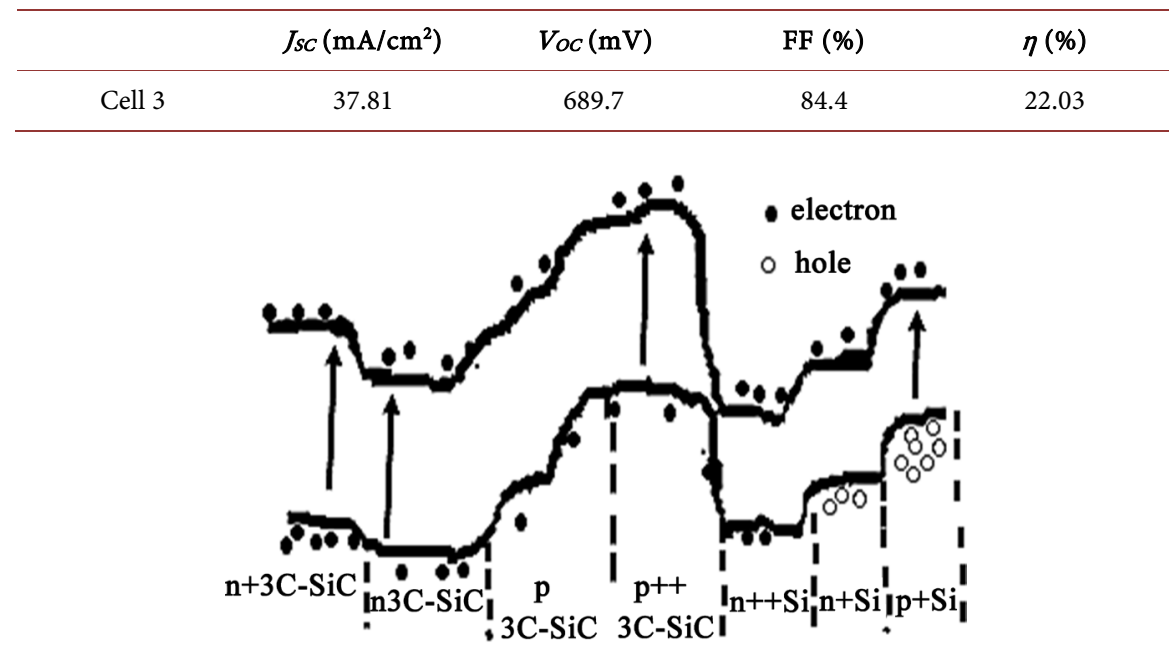

Figure 11. Carrier transport in tandem cell. 
first studies [12]. It is clearly seen that as the emitter layer is thinner, the current density is increased and achieved $37.81 \mathrm{~mA} \cdot \mathrm{cm}^{-2}$. This improvement of the current density leaded to the enhancement of the efficiency of $22.03 \%$ of the cell (Table 3).

For this result, it has been seen that the tandem cell has the best parameters of photovoltaic.

So, we present in the following Figure 12, the external quantum efficiency $\mathrm{EQE}$ of the tandem cell:

The spectral response which is defined as the ratio of the photogenerated short-circuit current $\left(I_{p h}\right)$ to the incident luminous power $\left(P_{i n}\right)$ upon the PV cell, is an intrinsic parameter for the specific cell in the course of the photovoltaic conversion. It can be expressed by [24]:

$$
S R(\lambda)=\frac{I_{p h}(\lambda)}{P_{i n}}
$$

This expression can be rewritten:

$$
S R(\lambda)=\lambda \frac{q}{h C} \operatorname{EQE}(\lambda)
$$

So, the following figure (Figure 13), present the evolution of the spectral response depends on the wavelength $(\mathrm{nm})$ of this tandem cell.

At the long wavelengths, the semiconductor is unable to absorb photons with energy below the band gap, so the response spectral is limited. We can see the same limit encountered in the quantum efficiency. However, at the short wavelengths, the spectral response decreases. At these short wavelengths, the energies of photons are high because: $E=\frac{h C}{\lambda}$.

So, the ratio of current generation to incidence power is limited.

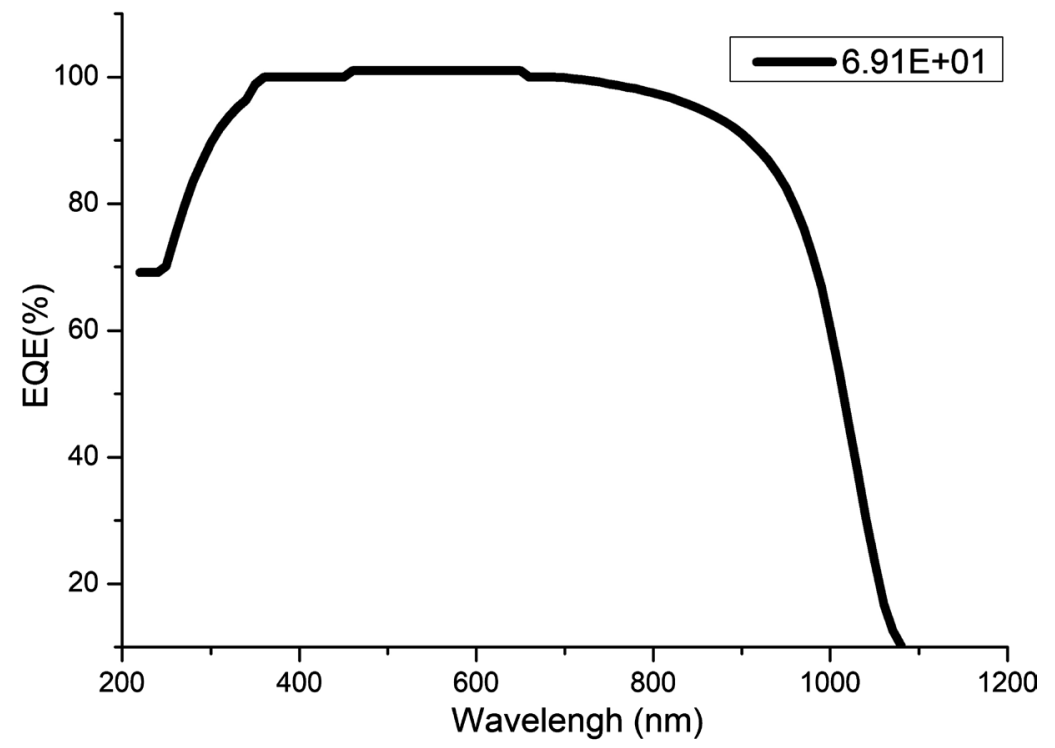

Figure 12. External quantum efficiency of the tandem cell. 


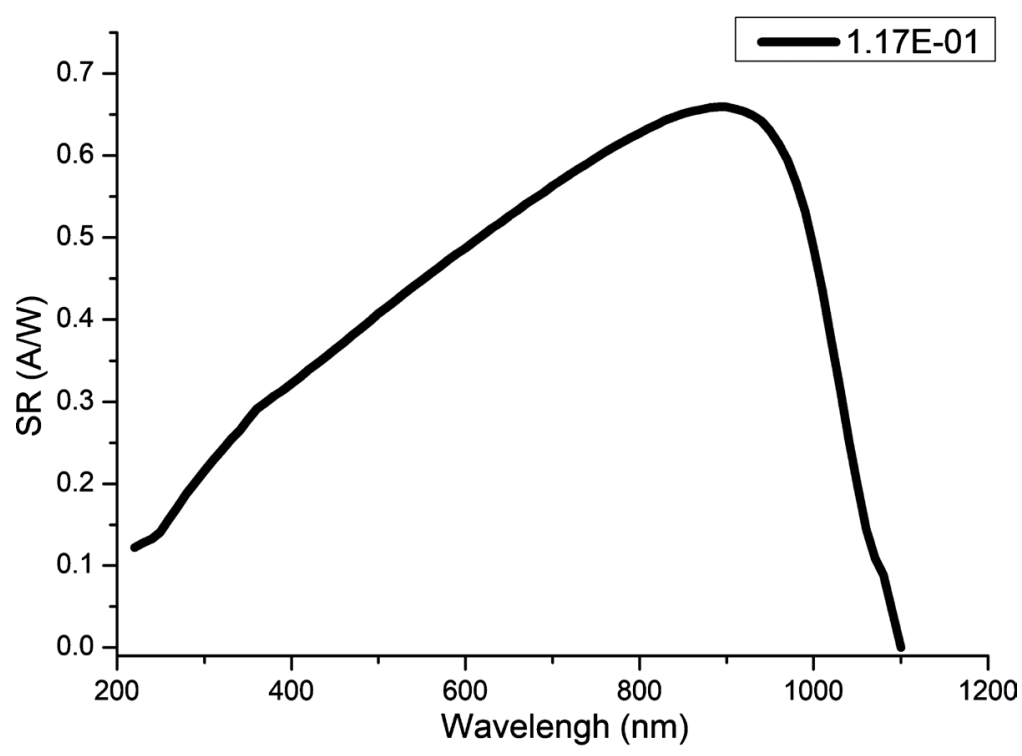

Figure 13. Spectral response of the tandem cell.

\section{Summary of Results}

Two different structures of cells were studied in this paper. The following Figure 14 presents the I-V characteristics of the two cells study, compared with the single junction cell.

This characteristic of current density -voltage, shows that we increase in current with an important open circuit voltage when we pass from a simple junction to a tandem cell. So, it was necessary in this study to show that with a tandem cell based on 3C-SiC, we obtain a good photocurrent.

Figure 15 recapitulates the results obtained for the short circuit current density $J_{s o}$ the open circuit voltage $V_{o o}$ the fill factor FF and the efficiency $\eta$ of the two cells studies.

From Figure 15, it can be seen that the best cell is cell 3 due to the optimization of the band structure and the layers' thicknesses. The good parameters of

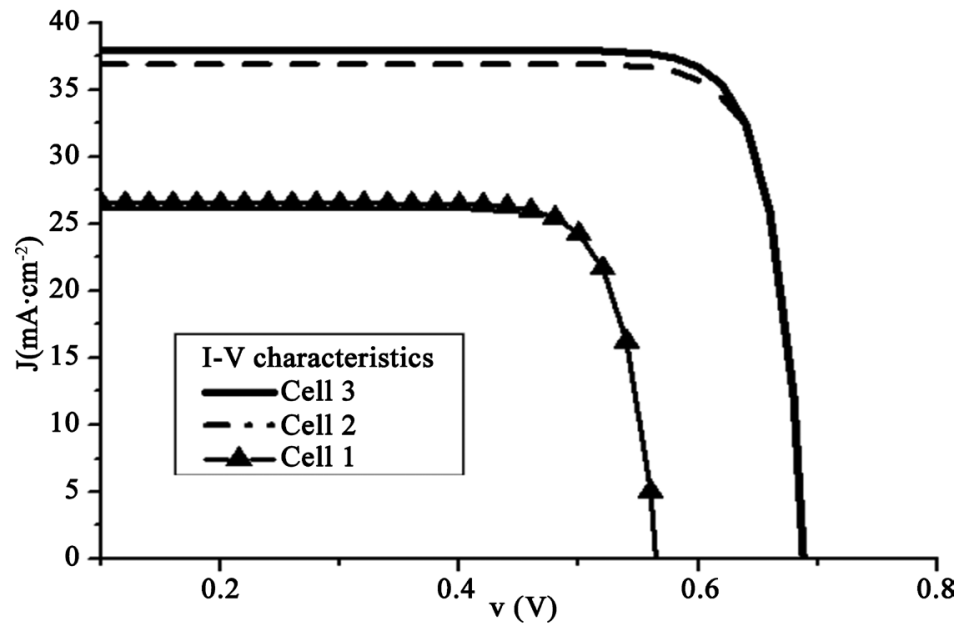

Figure 14. I-V characteristic of the cells. 


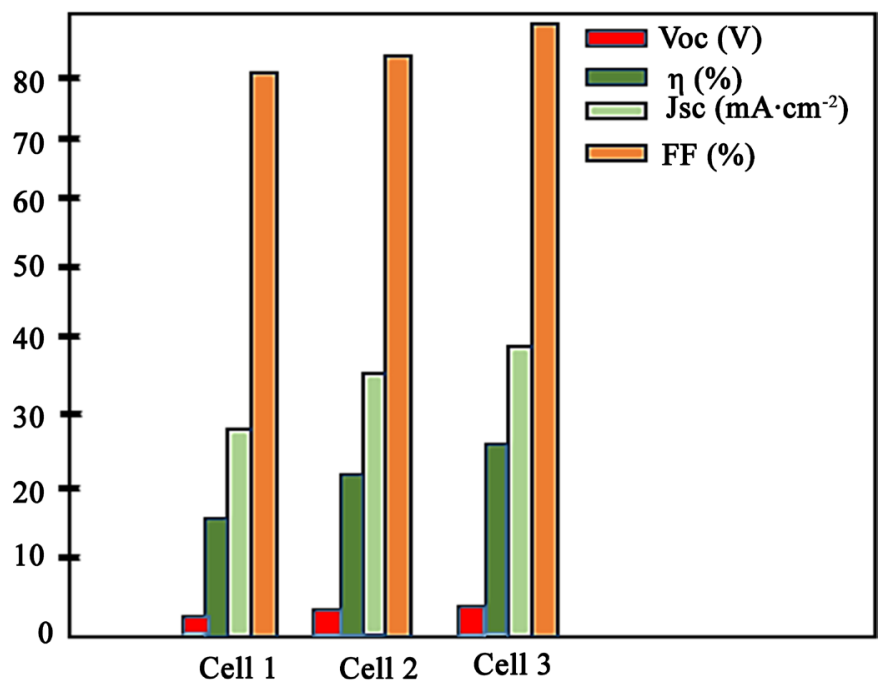

Figure 15. Photovoltaic parameters of the different cells.

photovoltaic are obtained by the tandem (cell 3). This difference comes from the different combination of materials as well as their diagram band to absorb the photons, generate charges, transport and collect them.

\section{Conclusions}

A study of three silicon carbide 3C solar cells structures by simulations with SCAPS software has been presented in this paper. First, we studied a simple cell heterojunction and then secondly, with the aim of widening the space charge area in order to capture more photons, and with a justaposition of less possible materials which could allow a reduction in the cost of materials which can be used, we simulated this time, multi-layered cells called multi-junction cells. The results showed that each cell has presented different efficiency. So, the single junction $\mathrm{n}+\mathrm{SiC} / \mathrm{Si}$, presented an efficiency of $17.49 \%$, and the second cell $\mathrm{n}+$ $\mathrm{SiC}-3 \mathrm{C} / \mathrm{pSiC}-3 \mathrm{C} / \mathrm{Si}(\mathrm{i}) / \mathrm{n}+\mathrm{Si} / \mathrm{p}+\mathrm{Si}$ : the efficiency was $21.68 \%$; and then, for the tandem cell 3C-SiC(n+)/3C-SiC(n)/3C-SiC (p)/3C-SiC $(\mathrm{p}++) / \mathrm{Si}(\mathrm{n}++) / \mathrm{Si}(\mathrm{n}) / \mathrm{Si}(\mathrm{p}+)$, it presented an efficiency of $22.03 \%$.

The best results of this study allowed to achieve an efficiency of $22.03 \%$ with the tandem junction structure $3 \mathrm{C}-\mathrm{SiC}(\mathrm{n}+) / 3 \mathrm{C}-\mathrm{SiC}(\mathrm{n}) / 3 \mathrm{C}-\mathrm{SiC}(\mathrm{p}) / 3 \mathrm{C}-\mathrm{SiC}(\mathrm{p}++) /$ $\mathrm{Si}(\mathrm{n}++) / \mathrm{Si}(\mathrm{n}) / \mathrm{Si}(\mathrm{p}+)$ combining good band structure and optimized layers' thicknesses. Our study confirmed first, the importance of band ad equation and thickness optimization in the design of solar cells, and secondly confirmed that 3C-SiC can be used as a capital material to get acceptable solar cells.

\section{Conflicts of Interest}

The authors declare no conflicts of interest regarding the publication of this paper.

\section{References}

[1] Cheung, R. (2006) Silicon Carbide Microelectromechanical Systems for Harsh Environments. World Scientific, Singapore. https://doi.org/10.1142/p426 
[2] Kefif, K., Bouizem, Y., Belfedal, A., Sib, J.D., Benlakehal, D. and Chahed, L. (2018) Hydrogen Related Crystallization in Silicon Carbide Thin Films. Optik, 154, 459-466. https://doi.org/10.1016/j.ijleo.2017.10.083

[3] Saddow, S.E. (2012) Silicon Carbide Biotechnology: A Biocompatible Semiconductor for Advanced Biomedical Devices and Applications. Elsevier, Amsterdam.

[4] Sprouster, D.J., Koyanagi, T., Dooryhee, E., Ghose, S.K., Katoh, Y. and Ecker, L.E. (2018) Reprint of: Microstructural Evolution of Neutron Irradiated 3C-SiC. Scripta Materialia, 143, 176-180. https://doi.org/10.1016/j.scriptamat.2017.09.034

[5] Ogawa, S., Yoshida, N., Itoh, T. and Nonomura, S. (2007) Heterojunction Amorphous Silicon Solar Cells with n-Type Microcrystalline Cubic Silicon Carbide as a Window Layer. Japanese Journal of Applied Physics, 46, 518. https://doi.org/10.1143/JJAP.46.518

[6] Chang, P.-K., Hsu, W.-T., Hsieh, P.-T., Lu, C.-H., Yeh, C.-H. and Houng, M.-P. (2012) Improved Stability of Amorphous Silicon Solar Cells with p-Type Nanocrystalline Silicon Carbide Window Layer. Thin Solid Films, 520, 3096-3099. https://doi.org/10.1016/j.tsf.2011.11.082

[7] Tawada, Y., Tsuge, K., Kondo, M., Nishimura, K., Okamoto, H. and Hamakawa, Y. (1982) 8\% Efficiency a-SiC:H/a-Si:H Heterojunction Solar Cells. Fourth EC Photovoltaic Solar Energy Conference, Stresa, 10-14 May 1982, 698-703. https://doi.org/10.1007/978-94-009-7898-0 114

[8] Chung, G.S., Kim, K.S. and Yakuphanoglu, F. (2010) Electrical Characterization of $\mathrm{Au} / 3 \mathrm{C}-\mathrm{SiC} / \mathrm{n}-\mathrm{Si} / \mathrm{Al}$ Schottky Junction. Journal of Alloys and Compounds, 507, 508-512. https://doi.org/10.1016/j.jallcom.2010.08.004

[9] Tanner, P., Dimitrijev, S. and Harrison, H.B. (2008) Current Mechanisms in n-SiC/p-Si Heterojunctions. 2008 Conference on Optoelectronic and Microelectronic Materials and Devices, Sydney, 28 July-1 August 2008, 41-43. https://doi.org/10.1109/COMMAD.2008.4802088

[10] Heidarzadeh, H., Baghban, H., Rasooli, H., Dolatyari, M. and Rostami, A. (2014) A New Proposal for Si Tandem Solar Cell: Significant Efficiency Enhancement in 3C-SiC/Si. Optik, 125, 1292-1296. https://doi.org/10.1016/j.ijleo.2013.08.018

[11] Biondo, S., Vervisch, W. and Ottaviani, L. (2014) Optical and Electrical Simulations of Solar Cell Based on Silicon and Silicon Carbide. Materials Science Forum, 778-780, 1050-1053. https://doi.org/10.4028/www.scientific.net/MSF.778-780.1050

[12] Kabe, M., Lare, Y., Ottaviani, L., Pasquinelli, M., Barakel, D. and Portail, M. (2019) Simulation and Optimization of a $\mathrm{nSiC}$ Layer's Thickness in a $\mathrm{nSiC} / \mathrm{pSi}$ Photovoltaic Solar Cell. OAJ Materials and Devices, 4, 3103.

[13] Burgelman, M., Verschraegen, J., Degrave, S. and Nollet, P. (2004) Modeling Thin-Film PV Devices. Progress in Photovoltaics. Research and Applications, 12, 143-153. https://doi.org/10.1002/pip.524

[14] Burgelman, M., Nollet, P. and Degrave, S. (2000) Modelling Polycrystalline Semiconductor Solar Cells. Thin Solid Films, 361-362, 527-532. https://doi.org/10.1016/S0040-6090(99)00825-1

[15] Casady, J.B. and Johnson, R.W. (1996) Status of Silicon Carbide (SiC) as a Wide-Bandgap Semiconductor for High-Temperature Applications: A Review. Solid-State Electronics, 39, 1409-1422. https://doi.org/10.1016/0038-1101(96)00045-7

[16] Green, M.A. (1990) Intrinsic Concentration, Effective Densities of States, and Effective Mass in Silicon. Journal of Applied Physics, 67, 2944-2954. https://doi.org/10.1063/1.345414 
[17] Beaucarne, G., Brown, A.S., Keevers, M.J., Corkish, R. and Green, M.A. (2002) The Impurity Photovoltaic (IPV) Effect in Wide-Bandgap Semiconductors: An Opportunity for Very-High-Efficiency Solar Cells? Progress in Photovoltaics. Research and Applications, 10, 345-353. https://doi.org/10.1002/pip.433

[18] Ludwig, G.W. and Watters, R.L. (1956) Drift and Conductivity Mobility in Silicon. Physical Review, 101, 1699-1701. https://doi.org/10.1103/PhysRev.101.1699

[19] Hemstreet, L.A. and Fong, C.Y. (1971) Energy Band Structure of 3C SiC. Solid State Communications, 9, 643-647. https://doi.org/10.1016/0038-1098(71)90236-5

[20] Bludau, W., Onton, A. and Heinke, W. (1974) Temperature Dependence of the Band Gap of Silicon. Journal of Applied Physics, 45, 1846-1848.

https://doi.org/10.1063/1.1663501

[21] Zielinski, M., Portail, M., Chassagne, T., Juillaguet, S. and Peyre, H. (2008) Nitrogen Doping of 3C-SiC Thin Films Grown by CVD in a Resistively Heated Horizontal Hot-Wall Reactor. Journal of Crystal Growth, 310, 3174-3182.

https://doi.org/10.1016/j.jcrysgro.2008.03.022

[22] Portail, M., Zielinski, M., Chassagne, T., Chauveau, H., Roy, S. and De Mierry, P. (2009) Highly Sensitive Determination of N+ Doping Level in 3C-SiC and GaN Epilayers by Fourier Transform Infrared Spectroscopy. Materials Science and Engineering. $B, 165,42-46$. https://doi.org/10.1016/j.mseb.2009.03.014

[23] Davydov, S.Yu. (2007) On the Electron Affinity of Silicon Carbide Polytypes. Semiconductors, 41, 696-698. https://doi.org/10.1134/S1063782607060152

[24] Wenham, S.R. (2011) Applied Photovoltaics. Routledge, Abingdon-on-Thames. 